\title{
Goos Cardol, Trudy Veerman, Annemieke Wolthuis (red.), Jongensbesnijdenis bezien vanuit mensenrechtelijk perspectief, Stichting NJCM-Boekerij 56 (Leiden: Stichting NJCM- Boekerij, 2015) $97 \mathrm{p}$.
}

\author{
Antoinette Muntjewerff
}

In Nederland worden per jaar 10.000 tot 15.000 jongetjes besneden. Het gaat hierbij voornamelijk om besnijdenis (circumcisie) op grond van religie, zonder medische noodzaak. Jongensbesnijdenis is een religieuze verplichting binnen het jodendom en een morele verplichting binnen de islam. In de discussie over jongensbesnijdenis staat daarom de vraag centraal hoe de godsdienstvrijheid van de ouders zich verhoudt tot de godsdienstvrijheid, het recht op lichamelijke integriteit en de keuzevrijheid van het kind. Jongensbesnijdenis staat opnieuw ter discussie door de uitspraak van het Landesgericht Köln van 7 mei 2012. De rechter heeft in deze zaak jongensbesnijdenis als een strafbare mishandeling gekwalificeerd. De werkgroep jeugdrecht en gezondheidsrecht van het Nederlands Juristen Comité voor de Mensenrechten (NJCM) nodigde deskundigen uit te schrijven over de reikwijdte van het recht op godsdienstvrijheid, over de vraag of het terecht is dat er zo verschillend wordt gedacht over meisjesbesnijdenis en jongensbesnijdenis en over de vraag of er al dan niet een verbod op jongensbesnijdenis zou moeten komen. Auteurs werd gevraagd te reflecteren op het onderwerp jongensbesnijdenis vanuit een mensenrechtelijk perspectief om een bijdrage te leveren aan de discussie over de al dan niet toelaatbaarheid van jongensbesnijdenis.

Rechtstheoreticus De Blois staat op het standpunt dat jongensbesnijdenis wordt beschermd door de godsdienstvrijheid. We hebben te maken met een religieuze praktijk, de jongensbesnijdenis, die thuishoort in het kader van de opvoeding van kinderen. De overheid dient zich terughoudend op te stellen als het gaat om het ouderlijk opvoedingsrecht, waartoe ook de religieuze en levensbeschouwelijke opvoeding behoort. Het staat de ouders vrij om hun kinderen op te voeden in een religieuze sfeer en in de gebruiken van die godsdienst, zolang de belangen van het kind daarbij vooropstaan. De Blois stelt dat in het publieke debat religie steeds vaker gepresenteerd wordt als een bedreiging voor individuele rechten.

De Blois stelt hiermee de ouderlijke opvoedingsvrijheid centraal, waarbij de belangen van het kind voorop dienen te staan. Hij gaat echter niet in op de vraag welke belangen van het kind deze opvoedingsvrijheid zouden kunnen beperken. Ook is 
De Blois tegen (te veel) inmenging van de overheid in de (religieuze) opvoeding. Maar bedenk dat de overheid zich, juist ook vanuit het belang van het kind, verregaand met de opvoeding bemoeit. Denk onder meer aan de zuigelingenzorg, de leerplicht, het drankverbod, de huwelijksleeftijd, het verbod op tatoeages bij minderjarigen.

Van der Wieken, voorzitter van het Centraal Joods Overleg, schrijft in de bundel over de joodse besnijdenis als een botsing van mensenrechten. Enerzijds het recht op fysieke integriteit van het kind, anderzijds het recht op geloofsvrijheid en het recht om godsdienst of levensovertuiging tot uiting te brengen in het inrichten van het gezinsleven en, meer in het bijzonder, in de opvoeding in overeenstemming met die overtuiging. Naar zijn mening dient in deze afweging de godsdienstvrijheid het zwaarst te wegen. Hierbij beroept hij zich op niet-juridische, historische argumenten.

Medisch ethicus Van Dijk bespreekt de vraag of beide vormen van besnijdenis echt zo verschillend zijn dat dit valt te rechtvaardigen. Van Dijk geeft duidelijk aan dat er geen medische voordelen zitten aan het besnijden van jongens. Hoewel in de joodse en islamitische cultuur jongetjes besneden worden vanwege religieuze voorschriften en niet vanwege medische of hygiënische voordelen, vormen deze laatste vaak een argument om tegenstand weg te wuiven.

Van Dijk vraagt zich af hoe het kan dat we meisjesbesnijdenis en jongensbesnijdenis zo verschillend beoordelen, terwijl er medisch, moreel en juridisch geen goede redenen voor te geven zijn. Terecht is meisjesbesnijdenis verboden waarmee de wet het grondwettelijk recht op lichamelijke integriteit van meisjes beschermt. $\mathrm{Nu}$ er geen redenen zijn om jongetjes anders te behandelen zou de wet dan niet ook de rechten van jongens moeten beschermen?

In de bundel zijn ook de officiële standpunten van de Koninklijke Maatschappij tot bevordering van de Geneeskunst (KNMG) en het instituut van de Kinderombudsman opgenomen. Het standpunt van de KNMG luidt dat er goede redenen zijn voor een wettelijk verbod op niet-therapeutische circumcisie bij minderjarige jongens, zoals dat ook bestaat voor vrouwelijke genitale verminking. De KNMG vreest echter dat een wettelijk verbod tot gevolg heeft dat de ingreep clandistien zal worden uitgevoerd met mogelijk extra ernstige gezondheidsrisico's. Terwijl meisjesbesnijdenis als genitale verminking wordt aangeduid en elke vorm van meisjesbesnijdenis in Nederland is verboden, is dit niet het geval voor jongensbesnijdenis. De Kinderombudsman stelt zich op het standpunt van de KNMG.

In de bundel geven Paul Vlaardingenbroek, Sabine de Jong en Goos Cardol hun standpunt over jongensbesnijdenis vanuit het perspectief van het kind.

Cardol gaat in op het recht op autonomie. Hij stelt dat het Internationaal Verdrag inzake de Rechten van het Kind (IVRK) geen expliciet recht op autonomie kent en dat het begrip autonomie voor de discussie of jongensbesnijdenis toelaatbaar is of niet, niet goed bruikbaar is vanwege gebrek aan eenduidigheid van de betekenis van het begrip. Hij pleit ervoor de belangen van het individu zwaarder te laten 
wegen. Onduidelijk is of hij hiermee doelt op de belangen van het kind of op de belangen van zowel de ouders als die van het kind.

Vlaardingenbroek beroept zich op het ouderlijk opvoedingsrecht, maar stelt tevens dat de belangen van het kind daarbij niet mogen worden geschaad. Het staat de ouders vrij om hun kinderen op te voeden in een religieuze sfeer en in de gebruiken van die godsdienst, zolang de belangen van het kind daarbij vooropstaan. Vlaardingenbroek stelt verder dat er binnen het recht vooral gereageerd wordt op jongensbesnijdenis vanuit het recht op de godsdienstvrijheid en het strafrecht. Hij vindt dat er meer onderzoek moet komen naar de mogelijkheden van het civiele recht als reactie op jongensbesnijdenis.

Niet alle aspecten en perspectieven komen in de bundel aan de orde. Het is de redactie niet gelukt een bijdrage te krijgen vanuit islamitisch perspectief noch vanuit strafrechtelijk perspectief.

De positie van het kind, het belang van het kind en de kinderrechten komen er in de bundel wat bekaaid af. Vijfentwintig jaar na de ratificatie van het IVRK zijn jeugdigen naast object van bescherming ook meer en meer subject van rechten. Nader onderzoek naar jongensbesnijdenis vanuit de positie van het kind zou een mooie aanvulling geven op de interessante bundel.

De bundel geeft stof tot nadenken en voer voor discussie ook voor andere religieuze voorschriften die ouders ten opzichte van hun kinderen hanteren. Denk hierbij aan het niet toestaan van vaccineren van hun kinderen of het niet toestaan van een bloedtransfusie voor hun kinderen.

Op 10 december 2015, de Dag van de Mensenrechten, organiseerde het NJCM onder leiding van Trudy Veerman een discussiebijeenkomst aan de Universiteit van Amsterdam rond het verschijnen van het boek Jongensbesnijdenis bezien vanuit mensenrechtelijk perspectief. Voor een volle zaal introduceerden twee auteurs hun bijdrage in de bundel en hun standpunt ten opzichte van jongensbesnijdenis. Rechtstheoreticus Matthijs de Blois sprak over jongensbesnijdenis en godsdienstvrijheid. Hij staat op het standpunt dat de ouderlijke opvoedingsvrijheid mede inhoudt dat ouders op grond van religie hun zoontjes moeten kunnen laten besnijden. Medisch-ethicus Gert van Dijk sprak over meisjesbesnijdenis en jongensbesnijdenis. Elke vorm van meisjesbesnijdenis is in Nederland verboden terwijl jongensbesnijdenis is toegestaan. Zijn beide vormen van besnijdenis echt zo verschillend dat dit valt te rechtvaardigen?

Ten slotte voerde forensisch arts en rechter Wilma Duijst een gedachte-experiment uit over een verbod op jongensbesnijdenis. Stel dat de Nederlandse wetgever besluit ook voor jongensbesnijdenis een verbod op te nemen in het Wetboek van Strafrecht, waar krijgen we dan strafprocesrechtelijk mee te maken?

Zowel de bijdragen in de bundel als de presentaties en discussie tijdens de bijzonder interessante bijeenkomst naar aanleiding van de bundel maken het mogelijk 
om jongensbesnijdenis in Nederland duidelijk te plaatsen als een op grond van religie vereiste (jodendom) dan wel gewenste (islam) handeling.

Dit betekent dat het hier gaat om de vrijheid van godsdienst. Het gaat echter ook om het recht op lichamelijke integriteit, waarbij we te maken hebben met een onomkeerbare ingreep. Het gaat om de vrijheid van godsdienst van de ouders ten opzichte van het recht op lichamelijke integriteit van het kind, de vrijheid van godsdienst van het kind en de keuzevrijheid van het kind. Waar de vrijheid van godsdienst ziet op de relatie overheid - ouders, gaat het bij het recht op lichamelijke integriteit in eerste instantie over de relatie ouder - kind. De overheid heeft hier echter ook een taak daar waar zij de kinderrechten moet waarborgen.

De meerderheid in de zaal was tegen jongensbesnijdenis, al liepen de standpunten over wel of geen strafrechtelijk verbod uiteen. Dat elke vorm van meisjesbesnijdenis bij wet verboden is in Nederland werd hier blijkbaar even vergeten. Tijdens de levendige discussie in de zaal vatte een deelneemster een en ander bondig samen: 'Blijf met je handen van de genitaliën van kinderen af.' 